\title{
"Rumah Cerdas Bina Diri" for Mentally Disabled in Banturejo Village, Ngantang District, Malang
}

\author{
Rizkha Khoirunnisa \\ Special Education \\ Faculty of Education \\ State University of Malang \\ rizkha.nisa22@yahoo.com \\ Luqyana Dhiya Amira \\ Special Education \\ Faculty of Education \\ State University of Malang \\ luqyanadhiya22@gmail.com
}

\author{
Anggita Yulia Giyanto \\ Special Education \\ Faculty of Education \\ State University of Malang \\ anggitacutezgirl@yahoo.co.id
}

\author{
Uut Fauziyah \\ Special Education \\ Faculty of Education \\ State University of Malang \\ ufauziach@yahoo.com
}

\author{
Atma Risanti \\ Special Education \\ Faculty of Education \\ State University of Malang \\ atmarisanti22@gmail.com
}

\begin{abstract}
Rumah Cerdas Bina Diri" for Mentally Disabled implemented in Banturejo Village, Ngantang District, Malang. In addition to the lack of knowledge about children with special needs, the community in Banturejo Village is still not aware of the importance of special education services for mentally disabled, whereas special education services are needed for children with mentally disabled, including selfservice capability. To overcome the problems in Banturejo Village, we created a program of "Rumah Cerdas Bina Diri" for Mentally Disabled which has several methods in its implementation. These methods include: (1) socialization, (2) counseling, (3) identification, (4) self-development activities, (5) cadre and (6) institutions strengthening. The results that want to achieve from this program are the dissemination of information about equitable mentally disabled, awareness of the importance of special education services for mentally disabled, closer recognition of mentally disabled children, training in self-development abilities for mentally disabled, and finding the successor of "Rumah Cerdas Bina Diri" for Mentally Disabled.
\end{abstract}

Keywords - mentally disabled, self-development, training

\section{INTRODUCTION}

In the world of education found children who have intelligence above the average child in general and fast in learning. Besides, there are also children who have the intelligence below average in general, children who have intelligence below the average child is generally called children retarded (mentally retarded), the official term used in Indonesia are children with intellectual challenges (PP No. 72 of 1991). Mentally Disabled children are children who significantly have intelligence below the average child in general with accompanying obstacles in adjustment to the surrounding environment [1].

Banturejo Village, Ngantang District, Malang is our target area in the implementation of the program "Rumah Cerdas Bina Diri for Mentally Disabled". It takes about 2 hours to get to the Banturejo Village, Ngantang District, Malang using motor vehicles and wheel vehicles 4. Until now in Banturejo village has never been any special program for children with special needs, especially for mentally disabled both in terms of education and develop the ability of self-development. Lack of knowledge about children with special needs becomes one of the problems faced in Banturejo Village. People are still less aware of the importance of special education services for children with special needs including mentally disabled. People do not understand that mentally disabled need special education services to support their daily life [2].

To solve the problem of self-development services for mentally disabled, we created a "Rumah Cerdas Bina Diri" for Mentally Disabled program. "Rumah Cerdas Bina Diri" for Mentally Disabled is a container for changing the behavior of the society towards the children's mentally disabled, providing new knowledge for the community about the children with special needs and to train the ability of selfdevelopment for mentally disabled. People with mental retardation can generally be identified by a slower process of thinking and learning than healthy children in general, for example, an 8-year-old child who still cannot communicate or write [3]. Generally, they also lack life skills to carry out their daily activities normally. Previously, people with this condition were said to have mental retardation, but this term was no longer used because it was considered less positive.

Most cases of mental retardation cannot be prevented, but pregnant women can always avoid harmful activities, such as consuming alcoholic beverages and receiving treatment until postpartum. In cases caused by hereditary diseases, a test can be applied to detect genetic disorders. Children with mental retardation have different levels of severity, but certainly, mentally retarded children need learning to be able to live independently like normal children in general [4]. They can learn everyday skills such as trying to travel using public transportation. Not infrequently after adulthood, they can also work like people in.

Basically, children with intellectual disabilities are recognized to have limitations in the following two main things. Limitations of intellectual function or IQ, namely the ability to learn, make decisions, find reasons, and solve issues. Mentally disabled children themselves have an IQ range of 70-75. Limitations on adaptability, as well as being effective, taking care of yourself, and using [5]. 


\section{METHOD}

To achieve the planned objectives, the implementation method used as follows.

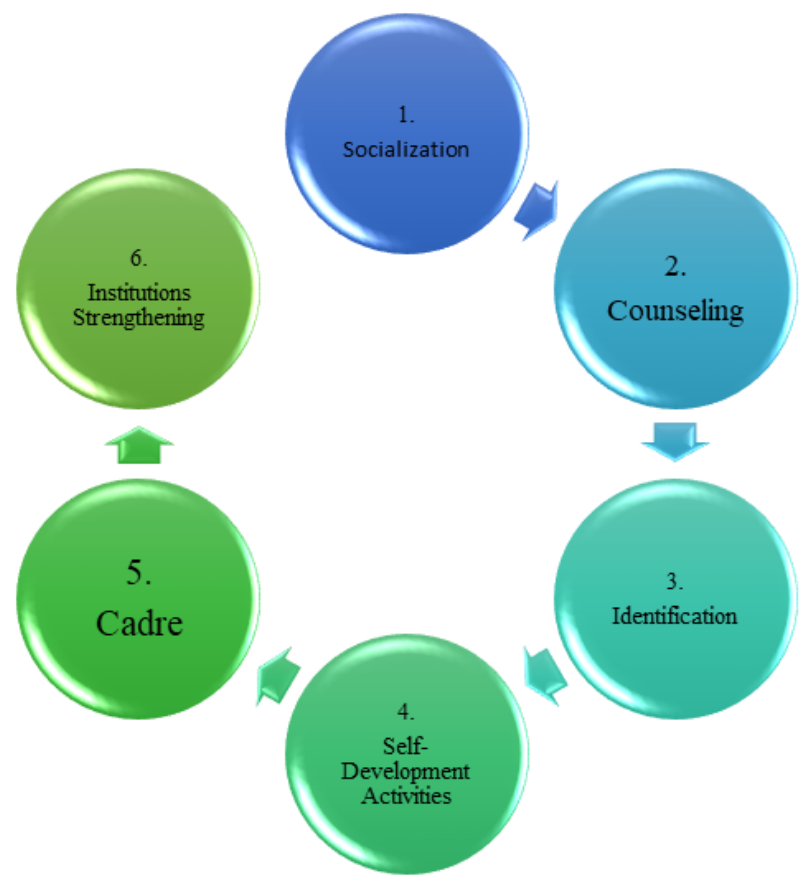

Fig. 1. Implementation method

\section{A. Socialization}

Socialization aims to provide new knowledge to the community in Banturejo Village about children with special needs including mentally disabled, self-care special services for mentally disabled as well as program "Rumah Cerdas Bina Diri" for Mentally Disabled. Implementation of the socialization conducted with Banturejo Village community.

\section{B. Counseling}

Extension aims to awaken the community to be able to accept children with special needs without hiding their existence. Counseling is also done so that special selfdevelopment programs can be implemented evenly.

\section{Identification}

Identification aims to group children with special needs based on the barriers they have. With this Identification, we will know which child with intellectual or tuna grahita obstacles in Banturejo Village.

\section{Self-Development Activities}

In this self-development activities is done by using modified monopoly media. Monopoly modification lies in a monopoly plot replaced with self-development activities.

\section{E. Cadre}

Cadre aims to form the manager team of "Rumah Cerdas Bina Diri" for Mentally Disabled. This cadre is also implemented so that the "Rumah Cerdas Bina Diri" for Mentally Disabled program can continue.

\section{F. Institutions Strengthening}

Institution strengthening aims to "Rumah Cerdas Bina Diri" for Mentally Disabled can implement the program well. Strengthening of this institution is done by debriefing all activities "Rumah Cerdas Bina Diri" for Mentally Disabled to form and train the manager team of "Rumah Cerdas Bina Diri” for Mentally Disabled in using media modification of monopoly.

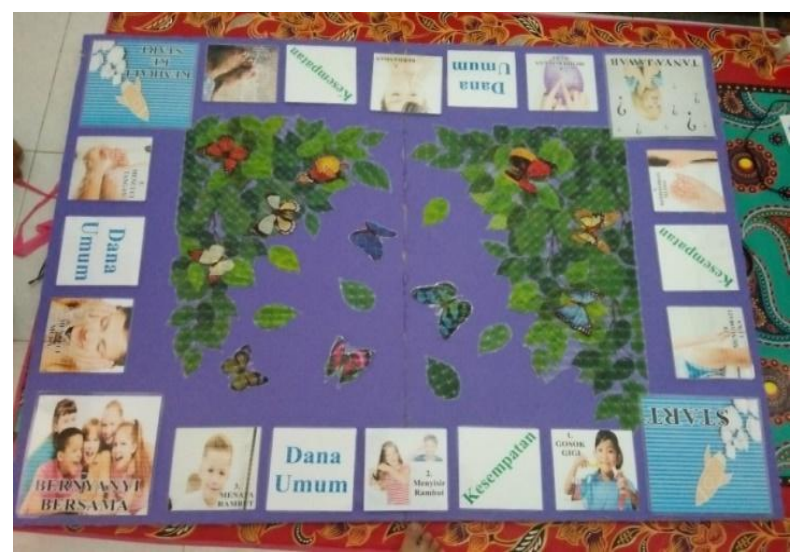

Fig. 2. Monopoly modification

\section{RESULT AND DISCUSSION}

The results achieved from the implementation of the Student Creativity Program "Rumah Cerdas Bina Diri" for Mentally Disabled as follows:

\section{A. Socialization reached $100 \%$}

Socialization in Banturejo Village about children with special needs and special education services have been implemented. We conduct socialization gradually and repeatedly, this we do so that people can really understand the new information about crews and appropriate education services. The purpose of gradual and repeated socialization is also to convince the community that the program we are implementing is a useful program to add insight and increase the expertise of every child mentally disabled in Banturejo Village.

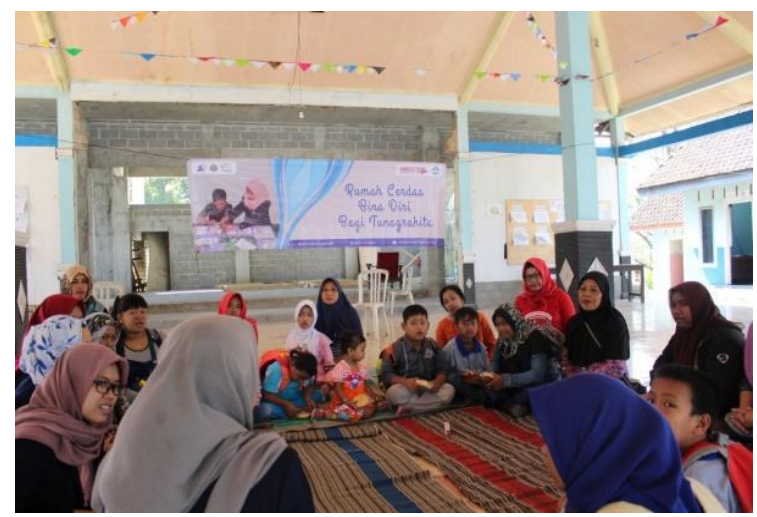

Fig. 3. Socialization in Banturejo Village

\section{B. Counseling reached $100 \%$}

Of the socialization that has been implemented, there are some parents with children with special needs are still reluctant to introduce their children before the wider 
community, because we do counseling. Every child with special needs is entitled to service an adequate life.

The team visited each of the children's homes with special needs to explain to parents about children with special need and the appropriate special services regarding the implementation program of "Rumah Cerdas Bina Diri" for Mentally Disabled.

\section{Identification reached $100 \%$}

This identification is carried out by approaching each child with special needs and understanding the characteristics, behaviors, and personality of the child to be classified including the child with which disturbances or obstacles [3]. Identification conducted in Banturejo Village known 7 children with barriers of intelligence or mentally disabled.

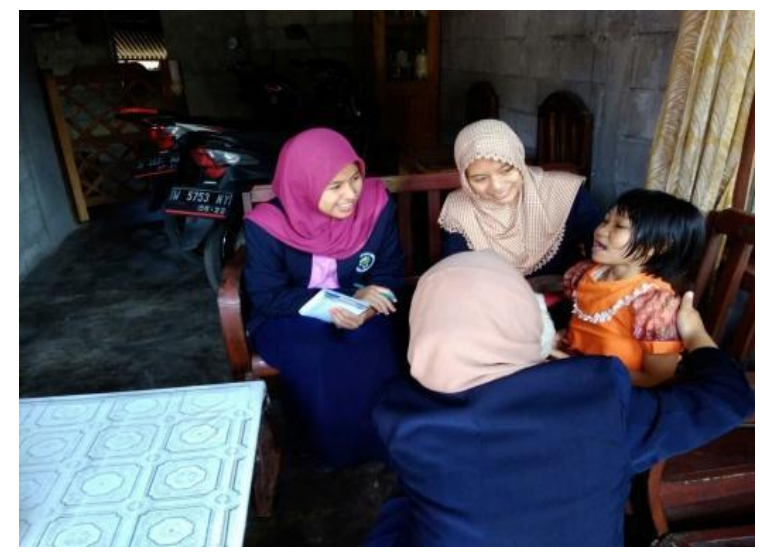

Fig. 4. Identification in Banturejo Village

\section{Self-Development Activities reached 100\%}

Self-Development Activities are implemented using modified monopoly game media. Self-development activity aims for children with mental ability self-development so that they can independently apply it in everyday life.

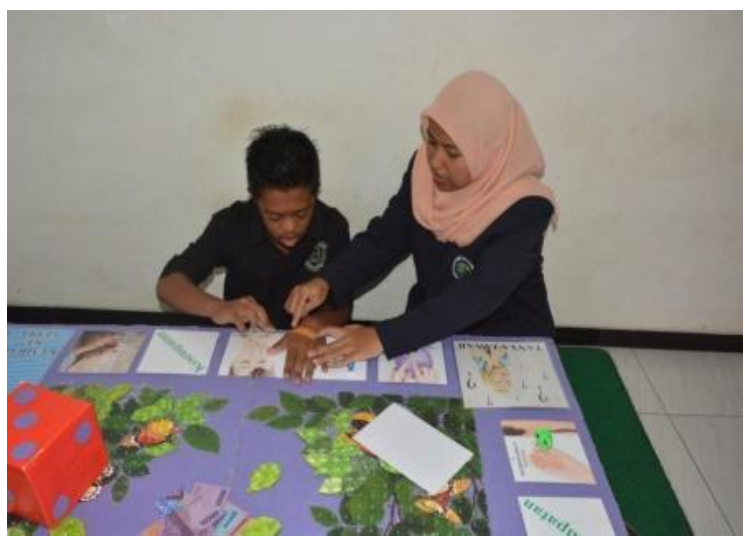

Fig. 5. Implementation modified monopoly game media

At the beginning of the self-development activities, we implement it in the home of one of the children with the mentally disabled involving the parents to be more convincing and to allow son follow the program that we offer. The next activity we do at the Village Hall so that parents and children with special needs more easily gather and interact.

\section{E. Cadre reached $100 \%$}

Cadre aims to form the successor team "Rumah Cerdas Bina Diri" for Mentally Disabled. Through the socialization that has been done, some residents are moved to become volunteer program that we offer.

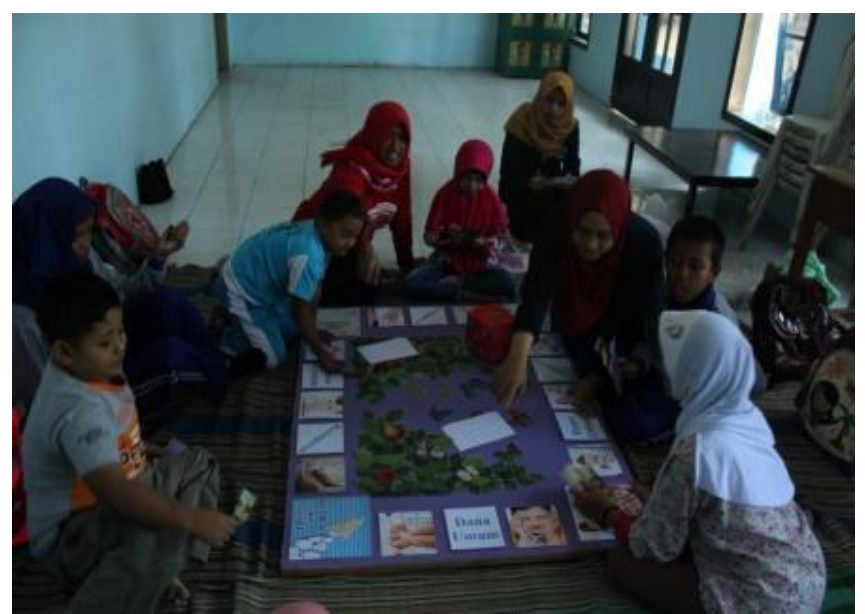

Fig. 6. Implementation modified monopoly game media

Currently we find 3 volunteers, among others: 1) Mr. Dio Saputro is a student who is studying high and taking concentration of Special Education, 2) Mrs. Yani is a villager of Banturejo who is very concerned with children with special needs, 3) Mrs. Dian a young woman from Banturejo Village who has special care and concern for children with special needs.

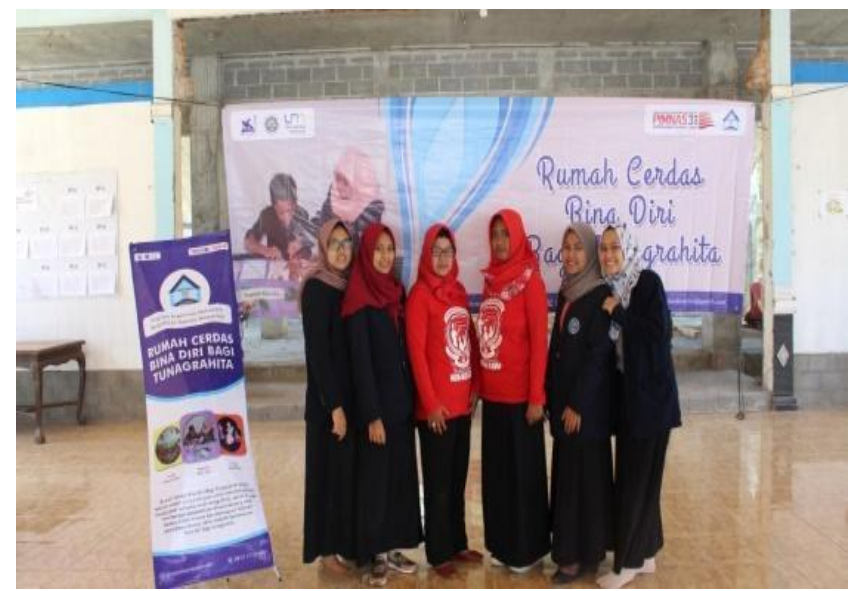

Fig. 7. Successor team "Rumah Cerdas Bina Diri for Mentally Disabled"

\section{F. Institutions Strengthening reached $100 \%$}

The method we use in strengthening this institution is to provide detailed training and explanation to the volunteers about the "Rumah Cerdas Bina Diri" for Mentally Disabled program and how it is implemented. For example how to use appropriate media, understand game rules, how to condition a child before, etc. With the strengthening of this institution is expected the volunteers can understand the implementation of this program appropriately.

\section{CONCLUSION}

The results achieved from the implementation of the Student Creativity Program "Rumah Cerdas Bina Diri" for Mentally Disabled as follows: the dissemination of information about equitable mentally disabled, awareness of 
the importance of special education services for mentally disabled, closer recognition of mentally disabled children, training in self-development abilities for mentally disabled, and finding the successor of "Rumah Cerdas Bina Diri" for Mentally Disabled in Banturejo Village, Ngantang District, Malang.

\section{ACKNOWLEDGMENTS}

Our thanks go to the Ministry of Research, Technology and Higher Education for the support and funding that has been given to the program. The author also thanked the Universitas Negeri Malang team that has guided the program.

\section{REFERENCES}

[1] Effendi, Mohammad. 2016. Pengantar Pendidikan Anak Berkebutuhan Khusus. Malang: Universitas Negeri Malang.

[2] Apriyanto, Nunung. 2012. Seluk Beluk Tunagrahita \& Strategi Pembelajarannya. Jogjakarta: Javalitera.

[3] Ramadhan, M. 2012. Pendidikan Keterampilan \& Kecakapan Hidup Untuk Anak Berkebutuhan Khusus. Jogjakarta: Javalitera.

[4] Sudrajat, Dodo. 2013. Pendidikan Bina Diri Bagi Anak Berkebutuhan Khusus. Bekasi: Luxima

[5] Ratih, Silviana. 2011. Bina Diri Anak Tuangrahita [online]. (http://silvianachita091044008.blogspot.com/2011/09/bina-diri-anaktunagrahita.html). accessed on May 29, 2018 